\title{
EFFECT OF SOME PRESERVATIVES ON BACILLUS CEREUS ISOLATED FROM SOME MEAT PRODUCTS
}

\author{
MOHAMED W.S. ${ }^{*}$ and GHANYEM H.R ${ }^{* *}$ \\ * National Center for Radiation Research and Technology (NCRRT)-Atomic Energy Authority. Nasr City, P.O.Box:7551, \\ Cairo, Egypt. \\ ${ }^{* *}$ Food Hygiene Dept Animal Health Research Institute, Tanta Lab., Egypt.
}

Email: wsmas1960@yahoo.com

Assiut University web-site: www.aun.edu.eg

\begin{abstract}
Received at: 22/4/2015

This study was carried out to evaluate the prevalence of Bacillus cereus in four types of meat products represented by minced meat, beef burger, sausage and Accepted: 15/6/2015 luncheon (20 of each) collected from different shops and supermarkets in Gharbia Governorate. The high incidence of B.cereus was recorded in minced meat samples (65\%) followed by sausage $(40 \%)$, beef burger (35\%) and luncheon (35\%). Minced meat samples were irradiated at $10 \mathrm{kGy}$ to ensure sterilization then being examined for studying the antimicrobial effect of some preservatives on isolated B.cereus from the different samples. The use of nisin 100g/ton in combination with potassium sorbate $2000 \mathrm{~g} / \mathrm{ton}$ resulted in decreased count of B.cereus by three $\log$ cfu/g. This combination have synergistic action and cause bactericidal and bacteriostatic effect on B.cereus.
\end{abstract}

Key Words: Bacillus cereus; nisin; potassium sorbate; meat products; food preservatives.

\section{INTRODUCTION}

Meat products such as minced meat, beef burger, sausage and luncheon are highly demined due to their high biological value, reasonable price, and agreeable taste and easy during serving (Soliman, 1999). Meat products are considered excellent media for the growth of many microorganisms including Bacillus cereus. On the other hand, meat products constitute public health hazard where bacteria are responsible for unfavorable changes or pathogenic microorganisms can lead to infection and intoxication (Kozareva et al., 1982). B.cereus food poisoning is a major concern worldwide. This bacterium is an aerobic spore-former commonly found in soil. It can be isolated from raw meat, processed foods and vegetables and entered into the food chain either through contaminated food or water. Food poisoning from the past outbreaks include boiled and fried rice, vegetables, cooked meats, soups, and raw vegetable sprouts (Food and Drug Administration, 2012). Certain strains of Bacillus cereus are capable of producing a heat- labile diarrheal enterotoxin and/or a heat- stable emetic enterotoxin, as well as other toxins leading to human gastroenteritis after ingestion of food containing preformed enterotoxins rather than a result of colonization or infection of host (Granum 1994).
Today, mankind depends on food additives; in fact, the industrialized world would not have been possible without them, USDA (2014). In order to ensure that the food reaches its destination in good conditions, special requirements are needed, mainly to prevent contamination and spoilage (Lerner et al., 2011). The food additive is a substance not normally consumed as a food by itself and not normally used as a typical ingredient of the food, whether or not it has nutritive value, the intentional addition of which to food for a technological (including organoleptic) purpose in the manufacture, processing, preparation, treatment, packing, packaging, transport or holding of such food (Carocho et al., 2014). Meat preservation became necessary for transporting meat for long distances without spoiling or changes in texture, color and nutritional value (Nychas et al., 2008). Traditional methods of meat preservation such as drying, smoking, brining, fermentation, refrigeration and canning have been replaced by new preservation techniques such as chemical, bio preservatives and non-thermal techniques (Zhou et al., 2010).

Voris and Stumbo (1965) mentioned that 650 compounds were tested as food preservatives. Antimicrobials which inhibit the growth of $B$. cereus include benzoate, sorbates and ethylene diamine tetraacetic acid (Jenson and Moir 2003). Generally, preservatives like nisin and potassium sorbate were 
approved by FAO (2012) after extensive testing and were safe.

Nisin is a preservative and antibacterial agent that is used to inhibit the germination and outgrowth of spores; it alters cell properties in bacteria to render it harmless. Nisin preparation is considered as safe for human consumption, FDA (2014); it may slow or stop squamous cell head and neck cancers; the Food and Drug Administration and the World Health Organization approved nisin as safe for human consumption decades ago (Joo et al., 2012).

Sorbic acid (2, 4-hexadienoic) and its salts are widely used throughout the world as meat preservative for inhibiting bacteria and fungi. A concentration of $0.3 \%$ sorbates in food is high enough to inhibit the microorganisms. The sorbic acid has an inhibitory mechanism via depression of internal $\mathrm{pH}$ (Feiner, 2006). Potassium sorbate is slightly acidic in nature with a $\mathrm{pH}$ of about 6.5 , when mixed in water it forms a weak acids solution of sorbic acid. The primary use of potassium sorbate is to increase the shelf life of various commercial products without causing any alteration in the taste, smell or color of the food (DJC, 2009). It is widely used in the packaging of canned fruits, vegetables, dairy products and meat products (beef and fish). The Canadian Food and Drug Act recorded that the allowable limit of potassium sorbate is 1000 ppm. Potassium sorbate, also known as E202, which serves as a preservative in a wide range of foods (Cassen, 1994 and Mamur et al., 2010).

Ionizing radiation typically is produced by Gamma radiators or electron accelerators and can kill microorganisms without increasing the temperature of irradiated material. Irradiation damages microbial cell components, including DNA and the cytoplasmic membrane. Irradiation sensitivity of foodborne microorganisms is affected by intrinsic and extrinsic factors. Microorganisms that exhibit increased radiation resistance seem to have efficient mechanisms for repairing damaged DNA (Mendonça and Daraba, 2014).

Aim of the work: The purpose of the current study was planned out to determine the incidence of B.cereus in different types of meat products such as minced meat, beef burger, sausage and luncheon as well as studying the effect of some preservatives on B.cereus.

\section{MATERIALS and METHODS}

1. Collection of samples: A total of 80 random samples of meat products; minced meat, beef burger, sausage and luncheon (20 of each) were collected from different shops, supermarkets and street vendors in Gharbia Governorate. Each sample was subjected to bacteriological examination for presence of B.cereus.

2. Preparation of samples: It was applied according to ICMSF (1974).

3. Isolation and Enumeration of B.cereus (Harrigan and McCane, 1976). From each previously prepared dilution, $0.1 \mathrm{ml}$ was seeded into the surface of the polymyxin-pyrovate - egg yolk-mannitol bromothymol blue agar (PEMBA). The inoculum was spread over the entire surface of the agar with a sterile bent glass rod and the plates were inverted and incubated at $37^{\circ} \mathrm{C}$ for 24 hours then examined for typical colonies of B.cereus which were turquoise to peacock blue color, about $5 \mathrm{~mm}$ in diameter and surrounded by a zone of egg yolk precipitation of the same color. The plates were re-incubated for further 24 hours in order to detect all B.cereus colonies. B.cereus count / $\mathrm{g}$ of the examined sample were calculated (the number of such colonies were multiplied by the reciprocal of the dilution that the countable plate represents) and recorded. Suspected colonies were picked up and subculture on nutrient agar slopes and incubated at $37{ }^{\circ} \mathrm{C}$ for 24 hours, then refrigerated at $40^{\circ} \mathrm{C}$ for further microbiological examination (Cruickshank et al., 1975) and biochemical identifications (Holbook and Anderson, 1980).

4. Antimicrobial effect of chemical preservatives on B.cereus isolated from some meat products. The effect of addition of some chemical preservatives (nisin, potassium sorbate, and combination of nisin, potassium sorbate) was studied on irradiated minced meat.

- Irradiation of minced meat samples: the samples were subjected to $10 \mathrm{kGy}$ of gamma radiation using the Indian Co-60 gamma cell type 4000A at the NCRRT (the National Center for Radiation Research and Technology in Cairo, Egypt). The gamma-cell gave a dose rate of $2.6 \mathrm{kGy} / \mathrm{h}$ at the time of experiment.

- Preparation of $\boldsymbol{B}$. cereus strain: B. cereus strains were grown on $B$. cereus selective agar medium for $24 \mathrm{hr}$ at $37^{\circ} \mathrm{C}$. Pure colonies were grown in nutrient broth at $37{ }^{\circ} \mathrm{C}$ for $24 \mathrm{hr}$ and streaked on B. cereus selective agar medium for $24 \mathrm{hr}$ at $37^{\circ} \mathrm{C}$. One colony was transferred to another $B$. cereus selective agar medium and incubated at $37{ }^{\circ} \mathrm{C}$ for $24 \mathrm{hr}$. Culture was transferred to nutrient broth and incubated at $37^{\circ} \mathrm{C}$ for $24 \mathrm{hr}$. A cell suspension to an approximate concentration of $8.87 \mathrm{log} \mathrm{cfu} / \mathrm{ml}$ was obtained depending upon the opacity of the culture (Baker and Breach, 1980). The produced suspension was used for experimental inoculation. 
- Preparation of sample: Meat was mixed aseptically, manually with growth of B.cereus in nutrient broth at $37^{\circ} \mathrm{C}$ for $24 \mathrm{hr}$ to reach possible maximum B.cereus count /g (Agata et al., 2002). Ten grams from the mixture was cultured and counted. B.cereus count $/ \mathrm{g}$ was $7.30 \mathrm{log} \mathrm{cfu} / \mathrm{g}$. then each part was classified into 8 groups A, B, C, D, E, F, G, H. Groups A, B, C, D, E, F and G were inoculated $B$. cereus suspension, while group $\mathrm{H}$ was considered as control negative (not inoculated with test strain). Group A was treated by $(0.025 \%) 100 \mathrm{~g} / \mathrm{ton}$ nisin, group B was treated by $(0.05 \% \%) 200 \mathrm{~g} / \mathrm{ton}$ nisin, group C was treated by $(0.075 \%) 300 \mathrm{~g} /$ ton nisin, group D was treated by $1000 \mathrm{~g} /$ ton potassium sorbate. group E was treated by $2000 \mathrm{~g} / \mathrm{ton}$, potassium sorbate. Group $\mathrm{G}$ was treated by combination of $100 \mathrm{~g} / \mathrm{ton}$ nisin and $2000 \mathrm{~g} /$ ton potassium sorbate, while group $\mathrm{H}$ leaved without any treatment (considered as control positive). Then all inoculated and non-inoculated groups were stored in plastic bags at $4{ }^{\circ} \mathrm{C}$ in refrigerator, and examined bacteriologically at 1 st day and after $7^{\text {th }}$ day. All groups were removed aseptically from bags. Ten gm of each sample was homogenate with $90 \mathrm{ml}$ of buffered peptone water $0.1 \%$, then one $\mathrm{ml}$ from each homogenate was transferred into a tube containing $9 \mathrm{ml}$ peptone water, then tenfold serial dilution were obtained till $10^{7}$.

\section{5- Statistical analysis}

Whole experiment was conducted 2 times and the results were presented as means, standard deviation and the least significant difference test $\mathrm{p} \leq 0.05$ (Draper and Smith, 1998). All statistical procedures were computed using the Microsoft Excel 2007 in order to compare the mean values of the investigated parameters. The mean values obtained from chemical analysis of irradiated samples were compared with non-irradiated samples using the SPSS14 (2006) software. (Petrie and Watson, 1999) Differences were considered to be statistically significant with values of $\mathrm{P}<0.05$.

\section{RESULTS}

Table 1: Incidence of Bacillus cereus in the examined meat product samples.

\begin{tabular}{|c|c|c|c|c|}
\hline \multirow{2}{*}{ Samples $\quad(n=20)$} & \multicolumn{2}{|c|}{ Positive sample } & \multicolumn{2}{|c|}{ Negative sample } \\
\hline & No. & $\%$ & No. & $\%$ \\
\hline Minced meat (20) & 13 & 65 & 7 & 35 \\
\hline Beef burger(20) & 7 & 35 & 13 & 65 \\
\hline Sausage (20) & 8 & 40 & 12 & 60 \\
\hline Luncheon (20) & 7 & 35 & 13 & 65 \\
\hline Total (80) & 35 & 43.75 & 45 & 56.25 \\
\hline
\end{tabular}

Table 2: Statistical analytical results of B.cereus Count $(\log \mathrm{cfu} / \mathrm{g}$ ) of examined meat product samples.

\begin{tabular}{lccc}
\hline Samples(n=20) & Min. & Max. & Mean \pm S.D. \\
\hline Minced meat & 3.95 & 5.87 & $5.08 \pm 2.38^{\mathrm{a}}$ \\
\hline Beef burger & 2.69 & 4.60 & $4.22 \pm 1.48^{\mathrm{ab}}$ \\
\hline Sausage & 3.30 & 5.09 & $4.68 \pm 1.83^{\mathrm{ab}}$ \\
\hline luncheon & 2.84 & 4.30 & $3.90 \pm 0.72^{\mathrm{b}}$ \\
\hline
\end{tabular}

S. D = Standard Deviation of mean

a-b different letters within the same column differ significantly at $\mathrm{P}<0.05$

Data are expressed as mean log colony-forming units per gram. 
Table 3: Antimicrobial effect of Nisin and Pot. sorbate on the survival of B.cereus inoculated into irradiated minced meat after $24 \mathrm{hrs}$. $(\mathrm{n}=5)$.

\begin{tabular}{llll}
\hline Preservatives & Min. & Max. & Mean \pm S.D. \\
\hline Nisin100g/ton & 4.48 & 4.95 & $4.704 \pm .173^{\mathrm{b}}$ \\
\hline Nisin200g/ton & 2.60 & 3.30 & $2.965 \pm .279^{\mathrm{d}}$ \\
\hline Nisin300g/ton & 2.30 & 3.23 & $2.846 \pm .389^{\mathrm{d}}$ \\
\hline Pot.sorbat1000g/ ton & 5.45 & 5.78 & $5.632 \pm .139^{\mathrm{a}}$ \\
\hline Pot.sorbat2000g/ ton & 3.08 & 3.65 & $3.361 \pm .217^{\mathrm{c}}$ \\
\hline Nisin100g/ton+ Pot. sorbat2000g/ton & 2.30 & 3.15 & $2.826 \pm .384^{\mathrm{d}}$ \\
\hline
\end{tabular}

S.D = Standard Deviation of mean

a-b-c-d different letters within the same column differ significantly at $\mathrm{P}<0.05$

Data are expressed as mean log colony-forming units per gram.

Table 4: Antimicrobial effect of Nisin and Pot. sorbate on the survival of B.cereus inoculated into irradiated minced meat after 7 days $(n=5)$.

\begin{tabular}{lccc}
\hline Preservatives & Min. & Max. & Mean \pm S.D. \\
\hline Nisin100g/ton & 3.00 & 3.53 & $3.22 \pm .207^{\mathrm{b}}$ \\
\hline Nisin200g/ton & 2.30 & 3.30 & $2.86 \pm .383^{\mathrm{bc}}$ \\
\hline Nisin300g/ton & 2.30 & 3.11 & $2.68^{\mathrm{c}} \pm .365^{\mathrm{c}}$ \\
\hline Pot.sorbat1000g/ton & 4.08 & 4.75 & $4.39 \pm .264^{\mathrm{a}}$ \\
\hline Pot.sorbat2000g/ton & 2.85 & 3.30 & $3.07 \pm .183^{\mathrm{b}}$ \\
\hline Nisin100g/ton + Pot.sorbat2000g/ton & - & - & $2.00 \pm-\mathrm{d}<$ \\
\hline Control -ve & Deteriorated after four days & \\
\hline Control +ve & Deteriorated after two days & & \\
\hline
\end{tabular}

S.D. = Standard Deviation of mean

a-b-c-d different letters within the same column differ significantly at $\mathrm{P}<0.05$

Control negative (-ve) irradiated minced meat storage at $4{ }^{\circ} \mathrm{C}$

Data are expressed as mean log colony-forming units per gram.

Control positive (+ve) irradiated minced meat inoculated with $\log 7.00 / \mathrm{g}$ of B.cereus storage at $4{ }^{\circ} \mathrm{C}$.

\section{DISCUION}

Meat products are considered the main source of B.cereus contamination in meat; improper handling of meat products after cooking allow the spores of B.cereus to germinate and result in vegetative cells that multiply and lead to food poisoning (Torky, 2004 and FDA, 2012). The presence of B.cereus with high percentage in minced meat may be attributed to the storage in room temperature, high content of curing salts and spices in addition to cross contamination between raw and cooked products, besides all of the problems of fluctuation of temperature during cooking (Torky, 1995).

The results given in Table (1) reflected the presence of B.cereus in 7 samples from 20 Beef burger samples with an incidence of $35 \%$. Concerning the minced meat samples, it was found that out of 20 examined samples, B.cereus was isolated from 13 samples with an incidence of $65 \%$. The results showed that from 20 of sausage samples, 8 samples were positive with an incidence of $40 \%$. The given results reflected the presence of B.cereus in 7 samples out of 20 luncheon samples with an incidence of $35 \%$. The obtained findings proved to be similar to those reported by Torky (1995) who found that the incidence of B.cereus in sausage was $40 \%$. While, the higher incidence of $70 \%$ was recorded by Heikal et al. (2006). On the other hand, comparatively lower results of $28 \%, 30 \%$ B.cereus in sausage were reported by El-Sayed et al. (1999) and Eid et al. (2008). The obtained results were nearly similar to that recorded by El-Sayed et al. (1999) and ElGhamry (2004); they found that the incidence of B.cereus in minced meat was $58 \%$ and $55 \%$, respectively. On the other hand, comparatively lower results of $35 \%$ B.cereus in minced meat were reported by Hafez et al. (1990). Torky (1995) found that the 
incidence of B.cereus in beef burger was $40 \%$. While, the higher incidence of $48 \%$ and $65 \%$ were recorded by Ahmed (1991) and Heikal et al. (2006) respectively. The obtained results were lower than the results reported by Khalil (1997); they found that the incidence of B.cereus in luncheon was $50 \%$. The obtained results revealed that the meat products contained high B.cereus count and this may be attributed to contamination of flesh used for manufacture, mincing machine, grinders, equipments and knives also considered as source of contamination of meat during processing (ElMossalami et al., 1994).

From the result obtained in Table (2), the minimum, the maximum and mean values of B.cereus in examined samples were 2.69, $4.60 \mathrm{log} \mathrm{cfu} / \mathrm{g}$ and 4.22 $\log \mathrm{cfu} / \mathrm{g}$ for beef burger; $3.95 \mathrm{log} \mathrm{cfu} / \mathrm{g}, 5.87 \mathrm{log}$ cfu /g and $5.08 \mathrm{log} \mathrm{cfu} / \mathrm{g}$ for minced meat; $3.30 \mathrm{log}$ cfu /g, $5.09 \log \mathrm{cfu} / \mathrm{g}$ and $4.68 \mathrm{log} \mathrm{cfu} / \mathrm{g}$ for sausage and $2.84 \log \mathrm{cfu} / \mathrm{g}, 4.30 \mathrm{log} \mathrm{cfu} / \mathrm{g}$ and $3.90 \mathrm{log} \mathrm{cfu} / \mathrm{g}$ for luncheon. It is evident from the result achieved that the minimum B.cereus count was $3.95 \mathrm{log} \mathrm{cfu} / \mathrm{g}$ and the maximum was $5.87 \mathrm{log} \mathrm{cfu} / \mathrm{g}$ with a mean value of $5.08 \pm 2.38 \mathrm{log} \mathrm{cfu} / \mathrm{g}$. The minimum B.cereus count in beef burger was $2.69 \mathrm{log} \mathrm{cfu} / \mathrm{g}$ and the maximum was $4.60 \mathrm{log} \mathrm{cfu} / \mathrm{g}$ with a mean value of $4.22 \pm 1.48 \mathrm{log}$ cfu $/ \mathrm{g}$. Approximately similar findings were recorded by and Torky (1995) who found that the mean value was $1.6 \times 10^{3} \pm 0.7 \times 10^{3} \mathrm{cfu} / \mathrm{g}$. The obtained results were nearly similar to those reported by El-Sherif et al. (1991); they found an average B.cereus count of $3 \times 10^{4} \mathrm{cfu} / \mathrm{g}$. Heikal et al. (2006) recorded a mean value of $8.79 \times 10^{4} \pm 5.09 \times 10^{4} / \mathrm{g}$.

On the other hand lower counts were recorded by Lacona et al. (1995); they found that the count of B. cereus was $10^{2} / \mathrm{g}$. The minimum B.cereus count in sausage was $3.30 \mathrm{log} \mathrm{cfu} / \mathrm{g}$ and the maximum was $5.09 \mathrm{log} \mathrm{cfu} / \mathrm{g}$ with a mean value of $4.68 \pm 1.83 \mathrm{log}$ $\mathrm{cfu} / \mathrm{g}$. The minimum B.cereus count was $2.84 \mathrm{log}$ $\mathrm{cfu} / \mathrm{g}$ and the maximum was $4.30 \log \mathrm{cfu} / \mathrm{g}$ with a mean value of $3.90 \pm 0.72 \mathrm{log} \mathrm{cfu} / \mathrm{g}$. Eid et al. (2008) found that the mean value was $33.8 \times 10^{4} \pm 1.84 \times 10^{4} \mathrm{cfu}$ $/ g$. The results proved that some types of cooked products were possible to mishandling and temperature which lead to growth of $B$. cereus and toxin production as recorded by Smith et al. (2004).

Meat additives are considered the main source of $B$. cereus contamination in meat products. Improper handling of meat products after cooking allow the spore of B.cereus to germinate and resulting vegetative cells multiply and lead to food poisoning (Torky, Amal, 2004).

Concerning the results obtained in table (3); the use of nisin $100 \mathrm{~g} /$ ton in combination with pot. sorbate $2000 \mathrm{~g} /$ ton on irradiated and artificially inoculated raw minced meat showed decreased in the count of
B.cereus more than the use of Nisin $100 \mathrm{~g} /$ ton alone or pot. sorbate $2000 \mathrm{~g} /$ ton alone. The use of Nisin $300 \mathrm{~g} / \mathrm{ton}$ decreased the count of B.cereus to $2.68 \mathrm{log}$ cfu /g, the use of Nisin $200 \mathrm{~g} /$ ton decrease the count of B.cereus to $2.86 \mathrm{log} \mathrm{cfu} / \mathrm{g}$, the use of Nisin $100 \mathrm{~g} / \mathrm{ton}$ decreased the count of B.cereus to $3.22 \mathrm{log} \mathrm{cfu} / \mathrm{g}$, the use of pot. sorbate $1000 \mathrm{~g} / \mathrm{ton}$ decreased the count of B.cereus to $4.39 \log \mathrm{cfu} /$ while use of pot. sorbate $2000 \mathrm{~g} / \mathrm{ton}$ decrease the count of B.cereus to $3.07 \mathrm{log}$ cfu /g. Table (3) revealed that the addition of 3 concentrations of nisin (100, 200 and $300 \mathrm{~g} / \mathrm{ton})$ reduced $\log$ the count of inoculated $B$. cereus by 3-5 log cycles; similar results were recorded by Roberts and Hoover (1996) found that B.cereus initial count was reduced by three log cycles when Nisin concentration was 1.0 I.U. / ml. The addition of pot. Sorbate (1000 and $2000 \mathrm{~g} / \mathrm{ton})$ reduced $\log$ B.cereus by 2 and $4 \log$ cycles respectively. Feiner (2006) mentioned that a concentration of $0.3 \%$ sorbate was enough to inhibit B.cereus. The best result obtained by adding nisin $100 \mathrm{~g} / \mathrm{ton}$ in combination with potassium sorbate $2000 \mathrm{~g} /$ ton. as they have synergistic action (bacteriostatic and bactericidal).

Table (4) show that after 7 days; control negative (-ve) non-irradiated minced meat stored at $4{ }^{\circ} \mathrm{C}$ deteriorated after four days as a result of growth of different microorganisms. Control positive (+ve) irradiated minced meat inoculated with $\log 7.00 / \mathrm{g}$ of $B$. cereus stored at $4{ }^{\circ} \mathrm{C}$ deteriorated after two days due to multiplication of microorganisms. Aouadhia et al. (2015) found that the minimum inhibitory concentrations of nisin and potassium sorbate were $5 \times 10^{3} \mathrm{IU} / \mathrm{ml}$ and $2 \%$; they also found that nisin and potassium sorbate inhibited vegetative cell growth of $B$. sporothermodurans. Ávilaa et al. (2014) reported that nisin $(0.05-12.5 \mu \mathrm{g} / \mathrm{ml})$ was able to inhibit the growth of vegetative cells and spores of food born microorganisms. Arqués et al. (2004) proved that the antimicrobial activity of reuterin individually or in combination with nisin $(100 \mathrm{IU} / \mathrm{ml})$ against different food-borne Gram-positive and Gram-negative pathogens was increased.

\section{CONCLUSION}

The microbiological examination of food stuffs plays an important role in assuring the safety and quality of food. Even though the implantation of Hazard Analysis and Critical Control Point (HACCP) system (FDA's HACCP Programs 2009) and Good Manufacturing Practices emphasis to protect the consumers against food borne illness and production of maximum safety to consumers. It is recommended according to the results of this study to use nisin $100 \mathrm{~g} /$ ton in combination with potassium sorbate 2000 $\mathrm{g} /$ ton as they have synergistic action (bacteriostatic and bactericidal). 


\section{REFERENCES}

Agata, N.; Ohta, M. and Yokoyama, K. (2002): Production of Bacillus cereus emetic toxin (cereulide) in various foods. Int. J. Food Microbiol.73 (1): 23-27.

Ahmed, L.M.L. (1991): Hygienic quality of marketed ready to eat meat. M.V.Sc. Thesis meat Hygiene, Fac. Vet. Med., Zagazig University.

Arqués, J.L.; Fernández, J.; Gaya, P.; Nuñez, M.; Rodrigues, E. and Medina, M. (2004): Antimicrobial activity of reuterin in combination with nisin against food-borne pathogens. Int. J. Food Microbiol. 95(2, 1): 225-229.

Ávilaa, M.; Gómez-Torresa, N.; Hernándezb, M. and Gardea, S. (2014): Inhibitory activity of reuterin, nisin, lysozyme and nitrite against vegetative cells and spores of dairyrelated Clostridium species. Int. J. Food Microbiol. 172: 70-75.

Aouadhia, C.; Mejrib, S. and Maaroufia, A. (2015): Inhibitory effects of nisin and potassium sorbate alone or in combination on vegetative cells growth and spore germination of Bacillus sporothermodurans in milk. Food Microbiol. 46: 40-45.

Baker, F. and Breach, M. (1980): Medical microbiological Techniques. 1st Ed. Butter Worths, London-Boston.

Carocho, M.; Barreiro, M.F.; Morales, P. and Ferreiral, I.C.F.R. (2014): Adding Molecules to Food, Pros and Cons: A Review on Synthetic and Natural Food Additives. Comp. Rev. in Food Sci. and Food Safety. 13(4): 377399.

Cassens, R.G. (1994): Meat Preservation, Preventing Losses And Assuring Safety, 1st ed. Food and ISBN: 10: 9022004635. Nutrition Press, Inc. Trumbull, Connecticut, USA, pp: 79-92.

Cruickshank, R.; Duguid, J.P.; Marmion, B.P. and Swain, R.H.A. (1975): Medical Microbiology twelfth edition. Department of medical protozoology tropical medicine Churchill Livingstone. Edinburgh London, New York.

D.J.C. (2009): Food and Drug Act, Department of Justice Canada. http://laws.justice.gc.ca/en/ showtdm/cr/C.R.C.-c.870.

Draper, N.R. and Smith, H. (1998): Applied Regression Analysis. 3rd edn., John Wiley, New York, pp: 131-153

EL-Ghamry-Sanya, R. (2004): Incidence and public health importance of Bacillus cereus in meat and some meat products. M.V.Sc. Thesis Meat Hygiene, Fac. Vet. Med., Zagazig University.

El Sayed, M.; Ahmed, M.A. and El-Nagar, Sh.M. (1999): Prevalence of Bacillus cereus in minced meat and sausage and its susceptibility to some antibiotics in Dakahlia Governorate, Egypt. Zagazig Vet. Med. J. 27(4): 71-75.
El-Sherif-Amal, M.; Khalaf-Alla, F.A. and Darwish, A.M. (1991): Microlofra in Beef burger sandwiches. J. Egypt. Vet. Med. Assoc. 51 (182): 169-177.

Eid-Amal, M.; Eleiwa-Nesreen, Z.H. and Zaky-Eman, M.S. (2008): Prevalence of Bacillus cereus in some ready-to-eat meat products. 9th vet Med. Zag. Conference. 20-22 August Port-Said.

EL-Mossalami, M.K. (1994): Occurrence, species differering and enterotoxin buildings assets of aerobic spore formers in various meat products. Ph.D. Thesis, The Veterinamedizin at Freie Universitat, Berlin. Feiner, G. 2006. Meat products handbook: Practical science and technology. CRC Press, Cambridge, England. pp. 73-74, 112-113.

FAO "food and Agriculture Organization of the United Nations" Rome, (2012): The state of food insecurity in the world 2012: Economic growth is necessary but not sufficient to accelerate reduction of hunger and malnutrition. On line.

Feiner, G. (2006): Meat products handbook: Practical science and technology. CRC Press, Cambridge, England. pp. 73-74, 112-113.

FDA's HACCP Programs (2009): The United States Food and Drug Administration, Managing Food Safety: a HACCP Principles Guide for Operators of food Establishments at Retail Level.

FDA Food and Drug Administration (2012): Bacillus cereus. Downloaded from http://www.fda.gov/ Food/Science Research/Laboratory Methods/ Bacteriological Analytical Manual BAM/ ucm 070875.

FDA Food and Drug Administration (2014): Overview of Food Ingredients, Additives \& Colors. International Food Information Council (IFIC) and U.S. Food and Drug Administration. November 2004; revised April 2010.

Granum, P.E. (1994): Bacillus cereus, (ed). Food microbiology. Fundamentals and frontiers. American Society for Microbiology, Washington. D.C.

Hafez, A.E.; EL-Atabany, A.L.; EL-Kelish, H.L. and Morshdy, A. (1990): Bacillus cereus in some meat products. Zagazig Vet. J., 18. 4.

Harrigan, W.F. and McCane, M.E. (1976): Laboratory methods in food and dairy microbiology. Academic press. London. New York, San Francisco.

Heikal, G.I.; Khafagi, N.I.M. and Mostafa, N.Y. (2006): Bacillus cereus in some ready to cook meat products. Benha Vet. Med. J. 17(2): 343-350.

Holbook, R. and Anderson, J.M. (1980): An improved selective and diagnostic medium for isolation and enumeration of Bacillus cereus in 
foods. Canadian J. of Microbiol. 26 (7): 753- 759.

ICMSF "International commission on microbiological specification of foods" (1974): Microorganisms in foods, 2 sampling for Bacteriological analysis: principal and specific applications. University of Toronto Press. Toronto. Ontario Canada.

Jenson, I. and Moir, C.J. (2003): Bacillus cereus and other Bacillus species. Ch 14 In: Hocking AD (ed) Foodborne microorganisms of public health significance. $6^{\text {th }}$ ed, Australian Institute of Food Science and Technology (NSW Branch), Sydney, p. 445-478.

Joo, N.E.; Ritchie, K.; Kamarajan, Di Miao, $P$ and Kapila, Y.L. (2012): Nisin, an apoptogenic bacteriocin and food preservative, attenuates HNSCC tumorigenesis via CHAC1. An. Cancer Med.; 1(3): 295-305.

Khalil, B.G. (1997): Incidence of Bacillus cereus in some food stuffs with special references to its production of thermonouclease enzyme in Assuit City. Assuit Vet. Med. J. 75, 55-63.

Kozareva, M.; Enikova, R.; Smova, B. and Lordanova, M. (1982): Proteolytic activity of conditionally pathogenic microorganisms causing food poisoning. Vopr- Pitan., 1:53.

Lacona, V.A.; Simonetrta, A.C. and Renzulli, P.M. (1995): Bacteria of genus Bacillus in chicken carcasses and hamburgers. Renista Argentina de Microbiologia 27(1): 21-27.

Lerner, Sorensen, M. and Stromberg, P. (2011): Private Equity and Long-Run Investment: The Case of Innovation. J. of Finance, 66, (2) 445-477.

Mamur, S.; Yüzbaşioğlu, D.; Unal, F. and Yilmaz, S. (2010): Does potassium sorbate induce genotoxic or mutagenic effects in lymphocytes? Toxicol In Vitro. 24: 790-794.
Mendonça, A.F. and Daraba, A. (2014): NonThermal Processing|- Irradiation Encyclopedia of Food Microbiology (Second Edition), 954-961.

Nychas, G.J.E.; Skandamis, P.N.; Tassou, C.C. and Koutsoumanis, K.P. (2008): Meat spoilage during distribution. Meat Sci.78: 77-89.

Petrie, A. and Watson, P. (1999): Statistics for Veterinary and Animal Science 1st Ed. The Blackwell Science Ltd. Kingdom pp 90-99.

Roberts, C.M. and Hoover, D.G. (1996): Sensitivity of $B$. coagulance spore to combination of high hydrostatic pressure, heat, acidity and nisin. J. of Appl. Bacterial., 81:363.

Smith, D.P.; Berrang, M.E.; Felder, P.W.; Phillips, R.W. and meinersmann, R.J. (2004): Detection of $B$. cereus on selected retail chicken products. J. Food Product. 67: 1770-1773.

Soliman-Salwa, R. (1999): Risk of street food vending on public health. M.V.Sc. Thesis, Fac. Vet., Cairo University.

Torky-Amal, A.S. (2004): Trials for inhibition of some food poisoning microorganism in meat products. PhD. V. Sc. Thesi, Fac., Vet. Med., Cairo Univ.

Torky- Amal, A.S. (1995): Bactero- toxological studies of Bacillus cereus in meat products. M.V.Sc. Thesis, Fac. Vet. Med., Cairo Univ.

USDA (2014): United States Department of Agriculture, Food Safety and Inspection Service. Additives in Meat and Poultry Products. On line.

Voris, B.L. and Stumbo, C.R. (1965): Use of Nisin in processing food products J. Food Tech., April, 160-164.

Zhou, G.H.; Xu, X.L. and Liu, Y. (2010): Preservation technologies for fresh meat-A review. Meat Sci., 68. 119-128.

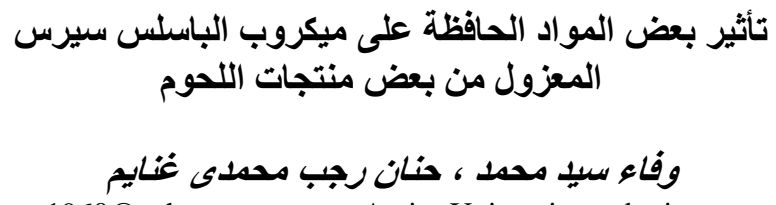

Email:wsmas1960@yahoo.com Assiut University web-site: www.aun.edu.eg

أجريت هذه الدر اسه على أربع أنواع من منتجات اللحوم (اللحوم المفرومه ـالبيف بيرجر ـ السجق و واللانشون) تم تجميعها من العديد

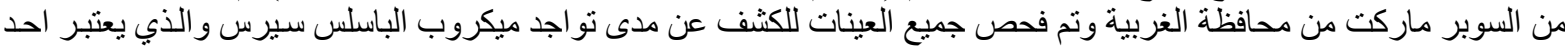

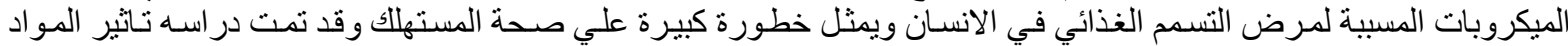

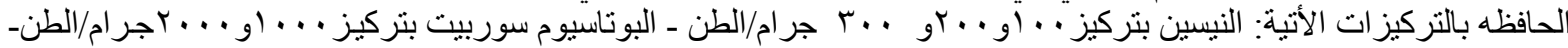

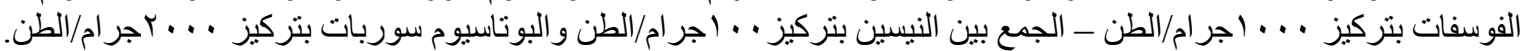

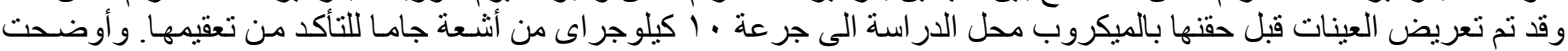

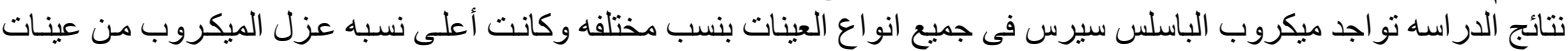

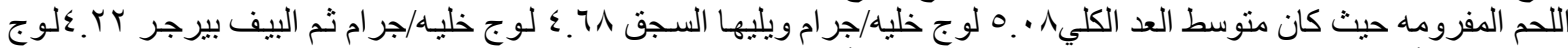

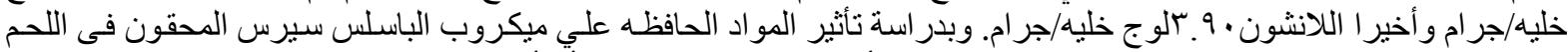

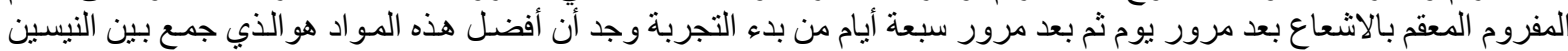

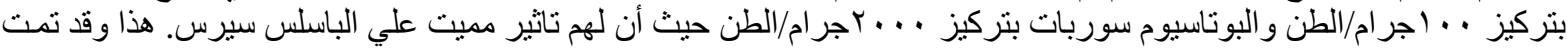
مناقشة الاجر اءت الصحيه الو اجب اتباعها لمنع تلوث منتجات اللحوم بهذا الميكروب للحد من خطورتها علي الصحة العامه. 